Amer. Soc. Hort. Sci. 74:206-213.

Kester, D.E. and W.H. Griggs. 1959b. Fruit setting in the almond: The pattern of flower and fruit drop. Proc. Amer. Soc. Hort. Sci. 74:214219.

Reina, A., V. Giorgio, and A. Godini. 1985. Autres types autocompatibles parmi la population d'a- mandiers des Pouilles. Options Medit., IAMZ 1:25-29.

Tufts, W.P. 1919. Almond pollination. Calif. Agr. Sta. Bul. 306.

Vasilakakis, M.D. and I.C. Porlingis. 1984. Selfcompatibility in 'Truoito' almond and effect of temperature on selfed and crossed pollen tube growth. HortScience 19:659-661.

Weinbaum, S.A. 1985. Role of natural self-pollination in self-fruitfulness of almond. Scientia Hart. 27:295-302.

Westwood, M.M., W.P. Stephen, and C.B. Cordy. 1966. The possibility of wind pollination in pear. HortScience 1:28-29.

\section{Defoliation of Strawberry Transplants for Fruit Production in Florida}

\author{
E.E. Albregts, C.M. Howard, and C.K. Chandler \\ Agricultural Research and Education Center, University of Florida, \\ I3138 Lewis Gallagher Road, Dover, FL 33527
}

\section{Additional index words Fragaria $\times$ ananassa}

\begin{abstract}
Florida-developed strawberry (Fragaria xananassa Duch.) clones or varieties grown in Florida nurseries and California-developed varieties grown in Canadian nurseries were evaluated in fruiting studies in Florida during four seasons. Transplants were defoliated so that $0 \%, 35 \%, 60 \%$, or $87 \%$ of the foliage was removed. The Florida clones 'Dover' and selection 79-1126 gave significant linear and/or quadratic early and total marketable yield responses to defoliation treatments for all seasons. The Canadian-grown clones 'Chandler' and 'Selva' gave similar responses during three seasons, but differences were not as great as for the Florida-grown clones. Many significant linear and quadratic responses in seasonal average fruit weight and plant size occurred for Florida-grown plants, but only one occurred with the Canadian-grown plants. Relative plant size at early and midseason decreased with greater defoliation.
\end{abstract}

Strawberry transplants used in the annual hill cultural system in Florida are produced locally for clones developed in Florida, while clones developed in California are generally produced in nurseries in the northern United States or southern Canada. The reasons for this are 2-fold. California clones grown in northern areas are less susceptible to anthracnose (Colletotrichum spp.) (a devastating disease in Florida) in the nursery and fruiting field than the same clones grown in Florida (Howard and Albregts, 1982). In addition, because of plant chilling and the shorter daylengths in the northern nurseries, plants stored in the roots when shipped to Florida (Bringhurst et al., 1960). Florida-developed plants flower 4 to 8 weeks later than the same plants from northern U.S. nurseries. Since Florida-developed plants are mostly plants is generally done in Florida because of lower costs. Locally produced plants are transplanted with foliage intact, since defoliation of these plants has been found to cause plant mortality and fruiting problems (Albregts and Howard, 1972). Regardless of origin, transplants are usually irrigated with overhead sprinklers during the daytime stress

Received for publication 23 Sept. 1991. Accepted for publication 18 Mar. 1992. Florida Agricultural Experiment Station Journal Series no. R-01842. The cost of publishing this paper was defrayed in part by the payment of page charges. Under postal regulations, this paper therefore must be hereby marked advertisement solely to indicate this fact. have flower buds in the crown and starch resistant to anthracnose, production of trans- period until established to reduce foliage loss. Irrigation for establishment could be reduced by as much as $50 \%$ and shipping costs would also be less if Canadian-grown plants could be defoliated before shipping or if Floridagrown plants could be partially defoliated before planting. With reduced foliage, foliage diseases and mites (Tetranychus urticae Koch) would have a lower probability of being transferred to the fruiting field, which might lower pesticide usage. However, for economic reasons, fruit production should not be delayed or reduced by defoliation.

The purpose of this study was to determine the effect of various amounts of defoliation on the plant growth and fruiting response of Florida- and Canadian-grown nursery plants.

Studies were conducted at Agricultural Research and Education Center (AREC), Dover, during four winter (October through April) seasons, 1987-88 through 1990-91, using the annual hill cultural system. The soil was a Seffner fine sand (sandy, siliceous, hyperthermic Quartzipsammentic Haplumbrepts). Transplants of 'Dover' and breeding line FL-79-1126 were produced at AREC-Dover, and 'Chandler' and 'Selva' transplants were produced in southern Ontario. 'Chandler' and 'Selva' transplants were not produced in Florida because of the problem with anthracnose as noted above. Raised beds were fertilized with $224 \mathrm{~N}-20 \mathrm{P}-184 \mathrm{~K}$ (kg-ha-r), fumigated with a $98 \%$ methylbromide and $2 \%$ chloropicrin mixture at 448 kg-ha-' of bed area and mulched with black polyethylene. Transplants were set on 27 Oct. 1987, 20 Oct. 1988 and 1989, and 22 Oct. 1990, with two rows per bed and plants spaced $30 \mathrm{~cm}$ between and $28 \mathrm{~cm}$ within rows. Overhead sprinkler irrigation and labeled pesticides were applied as needed. Defoliation treatments of plants consisted of measuring the height of the foliage and removing
Table 1. Early marketable fruit yields of strawberry (through January) during four seasons as affected by foliage removal and plant source.

\begin{tabular}{|c|c|c|c|c|c|}
\hline \multirow[b]{2}{*}{ Plant source } & \multirow{2}{*}{$\begin{array}{c}\text { Foliage } \\
\text { removed } \\
(\%)\end{array}$} & \multicolumn{4}{|c|}{ Early marketable fruit yield $\left(\mathrm{Mg}^{\prime} \mathrm{ha}^{-1}\right)^{\mathbf{z}}$} \\
\hline & & $1987-88$ & $1988-89$ & $1989-90$ & $1990-91$ \\
\hline Floriday & $\begin{array}{r}87 \\
60 \\
35 \\
0\end{array}$ & $1.4 \mathrm{~b}$ & $\begin{array}{r}4.1 \\
8.1 \\
9.3 \\
10.9\end{array}$ & $\begin{array}{l}1.7 \\
5.0 \\
5.6 \\
5.1\end{array}$ & $\begin{array}{l}2.9 \\
4.1 \\
5.7 \\
7.7\end{array}$ \\
\hline Significance & & & & & \\
\hline $\begin{array}{l}\text { Treatment } \\
\text { Linear } \\
\text { Ouadratic }\end{array}$ & & $*$ & $\begin{array}{l}* * * \\
* * * \\
*\end{array}$ & $\begin{array}{l}* * \\
* * * \\
* * *\end{array}$ & $* * *$ \\
\hline Canada & $\begin{array}{r}87 \\
60 \\
0\end{array}$ & $\begin{array}{l}4.6 \\
4.6\end{array}$ & $\begin{array}{r}6.5 \mathrm{~b} \\
10.3 \mathrm{a}\end{array}$ & $\begin{array}{l}4.6 \mathrm{~b} \\
4.6 \mathrm{~b}^{\mathrm{x}} \\
6.2 \mathrm{a}\end{array}$ & $\begin{array}{l}5.3 \\
6.3 \\
8.4\end{array}$ \\
\hline $\begin{array}{c}\text { Significance } \\
\text { Treatment } \\
\text { Linear } \\
\text { Quadratic }\end{array}$ & & NS & ** & $*$ & $\begin{array}{l}* * * \\
* * * \\
\text { NS }\end{array}$ \\
\hline
\end{tabular}

${ }^{2}$ Megagrams $/ 2.78=$ yield/plot in kilograms.

"1987-88 data are only for Florida-grown FL-79-1126, and 1987-88 and 1988-89 data are only for Canadian-grown 'Chandler'. All other data are averages of two clones.

"Defoliated $87 \% 2$ weeks before plant harvest.

Ns ****,***Nonsignificant or significant at $P=0.05,0.01$, or 0.001 , respectively, using ANOVA $\mathrm{F}$ test (treatment) and regressions. 
Table 2. Total marketable fruit yields during four seasons as affected by foliage removal and plant source.

\begin{tabular}{|c|c|c|c|c|c|}
\hline \multirow[b]{2}{*}{ Plant source } & \multirow{2}{*}{$\begin{array}{c}\text { Foliage } \\
\text { removed } \\
(\%)\end{array}$} & \multicolumn{4}{|c|}{ Total marketable fruit yield $\left(\mathrm{Mg} \cdot h \mathrm{a}^{-1}\right)^{\mathbf{z}}$} \\
\hline & & $1987-88$ & $1988-89$ & $1989-90$ & $1990-91$ \\
\hline Floriday & $\begin{array}{r}87 \\
60 \\
35 \\
0\end{array}$ & $16.5 \mathrm{~b}$ & $\begin{array}{l}14.3 \\
20.7 \\
23.6 \\
26.3\end{array}$ & $\begin{array}{l}16.0 \\
25.1 \\
28.1 \\
24.3\end{array}$ & $\begin{array}{l}12.1 \\
15.0 \\
17.1 \\
20.9\end{array}$ \\
\hline Significance & & & & & \\
\hline $\begin{array}{l}\text { Treatment } \\
\text { Linear } \\
\text { Quadratic }\end{array}$ & & * & $\begin{array}{l}* * * \\
* * * \\
\text { NS }\end{array}$ & $\stackrel{* *}{*}$ & $\begin{array}{l}* * * * \\
* * * \\
N S\end{array}$ \\
\hline $\begin{array}{l}\text { Quadratic } \\
\text { Canada }^{y}\end{array}$ & $\begin{array}{r}87 \\
60 \\
0\end{array}$ & $24.8 \mathrm{~b}$ & $16.3 \mathrm{~b}$ & $\begin{array}{l}13.7 \\
13.1^{x}\end{array}$ & $\begin{array}{c}\text { NS } \\
16.4 \\
18.7\end{array}$ \\
\hline $\begin{array}{c}\text { Significance } \\
\text { Treatment } \\
\text { Linear } \\
\text { Quadratic }\end{array}$ & 0 & $\begin{array}{c}27.7 \mathrm{a} \\
*\end{array}$ & $\begin{array}{c}19.4 \text { a } \\
*\end{array}$ & 15.2 & $\begin{array}{c}19.6 \\
* \\
* \\
\text { NS }\end{array}$ \\
\hline
\end{tabular}

${ }^{2}$ Megagrams $/ 2.78=$ yield/plot in kilograms.

'All data are averages of two clones, except data are only from Florida-grown n-79-1126 in 1987-88 and 'Dover' in 1989-90 and Canadian-grown 'Chandler' in 1987-88 and 1988-89.

${ }^{\times}$Defoliated $87 \% 2$ weeks before plant harvest.

Ns*******Nonsignificant or significant at $P=0.05,0.01$, or 0.001 , respectively, using ANOVA F test (treatment) and regressions.

Table 3. Average fruit weight as affected by foliage removal during four seasons.

\begin{tabular}{|c|c|c|c|c|c|}
\hline \multirow[b]{2}{*}{ Plant source } & \multirow{2}{*}{$\begin{array}{c}\text { Foliage } \\
\text { removed } \\
(\%)\end{array}$} & \multicolumn{4}{|c|}{ Avg fruit wt (g/fruit) } \\
\hline & & $1987-88$ & $1988-89$ & $1989-90$ & $1990-91$ \\
\hline Florida $^{2}$ & $\begin{array}{r}87 \\
60 \\
35 \\
0\end{array}$ & $\begin{array}{l}14.6 \mathrm{~b} \\
15.6 \mathrm{a}\end{array}$ & $\begin{array}{l}14.0 \\
15.8 \\
15.4 \\
15.7\end{array}$ & $\begin{array}{l}14.2 \\
15.3 \\
15.7 \\
15.4\end{array}$ & $\begin{array}{l}13.6 \\
13.8 \\
14.2 \\
14.4\end{array}$ \\
\hline Significance & & & & & \\
\hline $\begin{array}{l}\text { Treatment } \\
\text { Linear } \\
\text { Quadratic }\end{array}$ & & * & $\begin{array}{l}* * * \\
* * \\
* *\end{array}$ & $\begin{array}{l}* * * \\
* * \\
* * *\end{array}$ & $\begin{array}{l}* * \\
* * * \\
\text { NS }\end{array}$ \\
\hline Canada $^{\mathbf{z}}$ & $\begin{array}{r}87 \\
60 \\
0\end{array}$ & $\begin{array}{l}16.5 \\
16.5\end{array}$ & $\begin{array}{l}16.0 \\
15.2\end{array}$ & $\begin{array}{l}14.6 \mathrm{~b} \\
15.1 \mathrm{ab}^{y} \\
15.7 \mathrm{a}\end{array}$ & $\begin{array}{l}14.3 \\
14.8 \\
14.8\end{array}$ \\
\hline $\begin{array}{c}\text { Significance } \\
\text { Treatment } \\
\text { Linear } \\
\text { Quadratic }\end{array}$ & & NS & NS & ** & $\begin{array}{c}14.0 \\
* \\
\text { NS } \\
\text { NS }\end{array}$ \\
\hline
\end{tabular}

${ }^{2} 1987-88$ data are only for Florida-grown FL-79-1126, and 1987-88 and 1988-89 data are only for Canadian-grown 'Chandler'. All other data are averages of two clones.

'Defoliated $87 \% 2$ weeks before plant harvest.

Ns,*,**,***Nonsignificant or significant at $P=0.05,0.01$, or 0.001 , respectively, using ANOVA F test (treatment) and regressions.

a specific percentage. During the $1987-88$ season, clones FL-79-1126 and 'Chandler' were evaluated; treatments were $0 \%$ and $87 \%$ defoliation, which was carried out just before transplanting. The Florida clones for the subsequent seasons were 'Dover' and FL-791126 , from which $0 \%, 35 \%, 60 \%$, or $87 \%$ of foliage was removed just before transplanting. The Canadian-produced 'Chandler' plants had $0 \%$ and $87 \%$ of foliage removed the first two seasons. During the last two seasons, both 'Chandler' and 'Selva' were subjected to $0 \%, 60 \%$, or $87 \%$ defoliation. Foliage was removed just before transplanting, except for one of the two $87 \%$ defoliation treatments in 1989-90, when foliage was removed from Canadian plants 2 weeks before plant harvest.

Fruit harvest began in early December with fruit yield) (Table 1), except for 'Chandler' during the first season. Early fruit yields generally were reduced more with increasing defoliation. Canadian-grown plants defoliated in the nursery 2 weeks before plant harvest in the 1989-90 season also produced lower early yields than those not defoliated, but the same yield as plants defoliated $87 \%$ just before transplanting. However, total marketable yields of Canadian plants for the 1989-90 season for three treatments were similar (Table 2). For all other seasons, total marketable fruit yields of Canadian-grown plants increased with decreasing defoliation. A significant interaction between the Florida-grown clones and the defoliation treatments occurred in the 1989-90 season for total marketable yields. Only 'Dover' responded significantly to defoliation (Table 2; data for 79-1126 not shown). Average fruit weight varied with defoliation during all seasons with Florida-grown clones, and during 1989-90 and 1990-91 with Canadian-grown clones (Table 3). The greatest difference in fruit weight occurred between $87 \%$ and $0 \%$ defoliation. Except for one evaluation date for each plant source, plant size during the season appeared to be directly related to the amount of defoliation (Table 4). The percentage of marketable fruit was generally lowest with $0 \%$ defoliation, but differences were inconsistent (data not shown).

With Florida-grown clones, the percentage of the fruit rated cull because of small size $(<10 \mathrm{~g})$ generally increased with increasing defoliation (Table 5). Clones grown in Canada in 1987-88 and 1989-90 responded similarly. Thus, not only could marketable fruit be smaller because of defoliation (Table 3), but a greater percentage of the culls may not be marketable because of small size.

Florida-grown plants $35 \%, 60 \%$, or $87 \%$ defoliated had lower yields throughout the harvest season than those with $0 \%$ defoliation, except for $35 \%$ and $60 \%$ defoliation in 1989-90. The Canadian-grown plants were inconsistent as to when yield differences occurred because of defoliation treatments. The starch in the roots of Canadian-grown plants (Bringhurst et al., 1960) would enable faster growth of these plants than those grown in Florida, which are devoid of starch at the normal transplanting date because of the high ambient air temperature at plant harvest (Bringhurst et al., 1960). Because of small plant size at transplanting (see Table 4). Florida-grown clones that were partially defoliated may not have had sufficient photosynthetic capacity to fully support high early as well as seasonal fruit yields and yet allow normal growth of the plant.

Studies in California (Puffer et al., 1968) showed higher yields with defoliated plants. However, these plants were set in October and did not fruit until the following February, giving the plants considerable time to grow before fruiting. The reduction in early fruit yield of strawberry has economic implications. The price of fruit is generally highest during the period of early harvest in Florida (Freie and Young, 1991); thus, a re- 
Table 4. Relative plant size as affected by defoliation treatments during four seasons.

\begin{tabular}{|c|c|c|c|c|c|c|c|c|c|}
\hline \multirow[b]{3}{*}{ Plant source } & \multirow{3}{*}{$\begin{array}{c}\text { Foliage } \\
\text { removed } \\
(\%)\end{array}$} & \multicolumn{8}{|c|}{ Relative plant size ${ }^{x}$} \\
\hline & & \multicolumn{2}{|c|}{$1987-88$} & \multicolumn{2}{|c|}{ 1988-89 } & \multicolumn{2}{|c|}{ 1989-90 } & \multicolumn{2}{|c|}{$1990-91$} \\
\hline & & 12 Dec. & 9 Mar. & 30 Nov. & 7 Feb. & 30 Nov. & 29 Jan. & 14 Nov. & 25 Feb. \\
\hline Florida & $\begin{array}{r}87 \\
60 \\
35 \\
0\end{array}$ & $3.0 \mathrm{~b}$ & 10.6 & $\begin{array}{r}2.9 \\
7.7 \\
8.6 \\
10.0\end{array}$ & $\begin{array}{r}7.0 \\
8.3 \\
8.4 \\
10.0\end{array}$ & $\begin{array}{r}4.1 \\
8.8 \\
9.6 \\
10.0\end{array}$ & $\begin{array}{r}9.0 \\
9.3 \\
9.6 \\
10.0\end{array}$ & $\begin{array}{r}1.6 \\
2.8 \\
5.7 \\
10.0\end{array}$ & $\begin{array}{r}7.6 \\
8.6 \\
9.1 \\
10.0\end{array}$ \\
\hline $\begin{array}{c}\text { Significance } \\
\text { Treatment } \\
\text { Linear } \\
\text { Quadratic }\end{array}$ & & $m *$ & NS & $\begin{array}{l}* * * \\
* * * \\
* * *\end{array}$ & $\begin{array}{l}* * \\
* * * \\
\text { NS }\end{array}$ & $\begin{array}{l}* * * \\
* * * \\
* * *\end{array}$ & $\begin{array}{c}* \\
* \\
\text { NS }\end{array}$ & $\begin{array}{l}* * * \\
* * * \\
* *\end{array}$ & $\begin{array}{l}* * \\
* * \\
\text { NS }\end{array}$ \\
\hline Canada ${ }^{\mathbf{y}}$ & $\begin{array}{r}87 \\
60 \\
0\end{array}$ & $\begin{array}{r}8.3 \mathrm{~b} \\
10.0 \mathrm{a}\end{array}$ & $\begin{array}{r}8.9 \mathrm{~b} \\
10.0 \mathrm{a}\end{array}$ & $7.4 \mathrm{~b}$ & $\begin{array}{r}7.5 \mathrm{~b} \\
10.0 \mathrm{a}\end{array}$ & $\begin{array}{c}8.6 \mathrm{~b} \\
7.9 \mathrm{~b}^{\mathrm{x}} \\
10.0 \mathrm{a}\end{array}$ & $\begin{array}{c}9.5 \\
9.2^{\mathrm{x}} \\
10.0\end{array}$ & $\begin{array}{r}4.0 \\
5.7 \\
10.0\end{array}$ & $\begin{array}{r}9.1 \\
9.1 \\
10.0\end{array}$ \\
\hline $\begin{array}{c}\text { Significance } \\
\text { Treatment } \\
\text { Linear } \\
\text { Quadratic }\end{array}$ & & * & * & $* *$ & ** & $*$ & NS & $\begin{array}{l}* * \\
* * * \\
\text { NS }\end{array}$ & $\begin{array}{l}* \\
\text { NS } \\
\text { NS }\end{array}$ \\
\hline
\end{tabular}

${ }^{2}$ For each evaluation date, relative plant size in each plot was visually rated 1 (smallest) to 10 (largest). ${ }^{y} 1987-88$ data are only for Florida-grown FL-79-1126, and 1987-88 and 1988-89 data are only for Canadian-grown 'Chandler'. All other data are averages of two clones.

${ }^{x}$ Defoliated $87 \% 2$ weeks before plant harvest.

NS, $, * *, * * *$ Nonsignificant or significant at $P=0.05,0.01$, or 0.001 , respectively, using ANOVA F test (treatment) and regressions.

Table 5. Percentage of small fruit in cull during four seasons as affected by foliage removal and plant source.

\begin{tabular}{|c|c|c|c|c|c|}
\hline \multirow[b]{2}{*}{ Plant source } & \multirow{2}{*}{$\begin{array}{c}\text { Foliage } \\
\text { removed } \\
(\%)\end{array}$} & \multicolumn{4}{|c|}{ Small fruit in culls (\%) } \\
\hline & & $1987-88$ & $1988-89$ & $1989-90$ & $1990-91$ \\
\hline Floriday & $\begin{array}{r}87 \\
60 \\
35 \\
0\end{array}$ & $\begin{array}{c}86 \\
\cdots- \\
-- \\
75\end{array}$ & $\begin{array}{l}88 \\
82 \\
78 \\
77\end{array}$ & $\begin{array}{l}75 \\
63 \\
61 \\
61\end{array}$ & $\begin{array}{l}83 \\
79 \\
79 \\
74\end{array}$ \\
\hline $\begin{array}{l}\text { Significance } \\
\text { Treatment } \\
\text { Linear }\end{array}$ & & * & * & * & $*$ \\
\hline Canaday & $\begin{array}{r}87 \\
60 \\
0\end{array}$ & $\begin{array}{c}71 \mathrm{a} \\
--- \\
63 \mathrm{~b}\end{array}$ & $\begin{array}{l}64 \\
-- \\
66\end{array}$ & $\begin{array}{l}47 \mathrm{a} \\
44 \mathrm{ab}^{\mathbf{x}} \\
37 \mathrm{~b}\end{array}$ & $\begin{array}{l}73 \\
74 \\
75\end{array}$ \\
\hline $\begin{array}{l}\text { Significance } \\
\text { Treatment } \\
\text { Linear }\end{array}$ & & $*$ & NS & $*$ & $\begin{array}{l}\text { NS } \\
\text { NS }\end{array}$ \\
\hline
\end{tabular}

${ }^{2}$ Small cull fruit weighed $<10 \mathrm{~g}$.

'1987-88 data are only for Florida-grown FL-79-1126, and 1987-88 and 1988-89 data are only for Canadian-grown 'Chandler'. All other data are averages of two clones.

'Defoliated $87 \% 2$ weeks before plant harvest.

$\mathrm{NS},{ }^{*}$ Nonsignificant or significant at $P=0.05$, respectively, using ANOVA F test (treatment) and regressions. duction in early yield due to defoliation would result in a loss of income for growers.

Defoliation treatments were usually detrimental to early and total fruit production and reduced fruit and plant size. All of these responses were more severe on Florida- than on Canadian-grown transplants. The difference in response because of transplant source may be related to the chilling and shorter daylengths received by the Canadian-grown plants in the nursery (Bringhurst et al., 1960, Durner et al., 1986).

\section{Literature Cited}

Albregts, E.E. and C.M. Howard. 1972. Influence of defoliation at transplanting on strawberry growth and fruiting response. HortScience 7:569-570.

Bringhurst, R.S., V. Voth, and D. VanHook. 1960. Relationship of root starch content and chilling history to performance of California strawberries. Proc. Amer. Soc. Hort. Sci. 75:373-381.

Durner, E.F., E.B. Poling, and E.E. Albregts. 1986. Early season yield responses of selected strawberry cultivars to photoperiod and chilling in a Florida winter production system. J. Amer. Soc. Hort. Sci. 112:53-56.

Freie, R.L. and H.V. Young. 1991. Florida agricultural statistics vegetable summary 1989-90. Florida Agr. Stat. Serv., Orlando.

Howard, C.M. and E.E. Albregts. 1982. Strawberry anthracnose, crown rot, fruit rot, and black leaf spot caused by Colletotrichum fragariae. Dover AREC Res. Rpt. DOV-1982-2.

Puffer, R.E., V. Voth, H.J. Bowen, Jr., and R.H. Gupp. 1968. Effects of Alar and top removal on yield of Fresno strawberries at three digging dates. Calif. Agr. 22(2):11-13. 